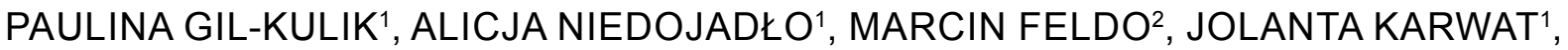
LIDIA KOTUŁA ${ }^{1}$, PIOTR CHOMIK ${ }^{1}$, ILONA DUDEK ${ }^{1}$, MAŁGORZATA FILAS ${ }^{1}$, AGNIESZKA WOJCIESZEK ${ }^{1}$, TOMASZ ZUBILEWICZ², ANNA BOGUCKA-KOCKA ${ }^{3}$, JANUSZ KOCKI ${ }^{1}$

\title{
The gene expression of class III inhibitors of apoptosis in arteriosclerotic disease
}

\begin{abstract}
Introduction. Recent research shows that programmed cell death has great importance in the pathomechanism of atherosclerosis. The BIRC5 and BIRC6 genes belong to Class III IAPs with the anti-apoptotic effect. The proteins display multidirectional action. According to the available literature, in addition to the effect of apoptosis inhibition they also display other properties. It is suggested that they play an important role in the processes of proliferation and cellular differentiation.

Aim. The aim of the study was to assess the expression of the BIRC5 and BIRC6 genes in normal peripheral blood lymphocytes and in peripheral blood lymphocytes of patients diagnosed with atherosclerosis.

Material and methods. The analysis was carried out on RNA samples obtained from peripheral blood lymphocytes of 21 patients with diagnosed atherosclerosis. The specific fragment of the analysed gene was obtained through amplification with the use of cDNA synthesised in the reaction of reverse transcription. The test of expression was conducted with the use of the Real-Time PCR method. In the studied cases, the level of expression of the analysed gene was compared to the level of expression of the reference gene, B2M.

Results. The study showed that mRNA of the BIRC5 and BIRC6 genes is present in the cells of patients with atherosclerosis, as well as in the cells of healthy individuals. The cells taken from the patients with atherosclerosis were mainly characterized by an increased gene expression in comparison to the normal cells.

Conclusion. Increased BIRC6 and BIRC5 gene expression in the cells of the patients with atherosclerosis can suggest an increased amount of the inhibitor protein BRUCE and survivin, and also decreased sensitivity of cells to apoptosis. In the case of the patients who had significantly higher expression of the BIRC6 gene in lymphocytes compared to the norm, hypertension and diabetes mellitus were more common.
\end{abstract}

Keywords: apoptosis, atherosclerosis, IAP, BIRC5 gene, BIRC6 gene.

DOI: $10.2478 /$ pjph-2014-0008

\section{INTRODUCTION}

Cardiovascular diseases are the most common cause of death among human population. They are mainly a result of atherosclerotic arterial wall restructuring. Atherosclerotic lesions cover many pathophysiological processes that take place in the blood vessel walls, such as the infiltration of inflammatory cells, an increase in the number of foam cells, the proliferation of the vascular smooth muscle cells and thrombotic lesions. One of the important pathogenetic elements of cardiovascular diseases is the action of free radicals. A significant element of this process is damage to the vessel endothelium which secretes many vasoactive substances. The interactions between the cells of blood vessel walls, blood cells, and lipoproteins present in plasma are disturbed. The oxidation of lipoprotein changes leads to the formation of lipid peroxides. As a result of phagocytosis of the oxidised lipoprotein particles, foam cells are formed.
A local dominance of oxidation processes, the excess of oxygen radicals and oxidized lipids. The effect of the free radicals action has a negative influence on the functions of endothelium halting the synthesis of prostacyclin and nitric oxide, and an increase in the synthesis of endothelin. Recent research shows that programmed cell death is of great importance in the pathomechanism of atherosclerosis [1-4].

Apoptosis can be induced in cells by a variety of signals such as death signals from other cells, as a result of growth inhibition or various types of environmental stress such as ionizing radiation, hyperthermia, chemotherapeutic agents [5-7].

The most important and irreversible stage of apoptosis is the activation of caspases. Caspases are enzymes belonging to the cysteine proteases. They are involved in the induction phase (caspases 2, 8, 9, 10) and in the execution phase of apoptosis (effector caspases $3,6,7$ ). In a cell, caspases may be found as inactive zymogens. Caspase activation can be external (receptorial) or internal (mitochondrial) [6-10].

\footnotetext{
${ }^{1}$ Department of Clinical Genetics, Medical University of Lublin, Poland

${ }^{2}$ Chair and Department of Vascular Surgery and Angiology, Medical University of Lublin, Poland

${ }^{3}$ Chair and Department of Pharmaceutical Botany, Medical University of Lublin, Poland
} 
Death signal receptor lane is triggered when ligands connect to membrane receptors. The receptor bound to the ligand combines adapter proteins that have the ability to connect to an inactive procaspase- 8 . The process is followed by the autocatalytic activation. Active caspase- 8 and caspase- 10 activate the caspase- 3 in the process of proteolysis, which in turn releases the $\mathrm{CAD}$ endonuclease. The CAD endonuclease transfers to the nucleus and causes fragmentation of the chromosomal DNA which leads to cell death [5-7].

Internal mechanism of apoptosis is carried out with the p53 protein and a number of proteins that modulate its activity. One of the proteins involved in the internal mechanism is Bax protein which is capable of opening the channels in the mitochondria membrane and releasing cytochrome c. Released cytochrome c together with protein Apaf-1, ATP, and initiator procaspase-9 create apoptosome in which procaspase- 9 undergoes an autocatalytic activation. Active caspase-9 initiates the activation of initiator caspases $[5,7,10]$.

"Apoptosis is a process regulated closely and on many levels by pro-and anti-apoptotic proteins. Among the proteins which play crucial role are: family of proteins Bcl-2 and p53, and family of inhibitors of apoptosis - IAP" [11]. Proteins of the Bcl-2 family are the products of cellular oncogenes and play an important role in the activation of caspases and release of cytochrome c. They may be divided into three groups: proteins which activate apoptosis, proteins which inhibit apoptosis and proteins which regulate the activity of Bcl-2 proteins. The proteins belonging to the family of IAP are in turn inhibitors of caspases, which prevent enzymes from spontaneous autoactivation $[9,10,12]$.

Proteins of IAP family (Inhibitor of Apoptosis Protein) are polypeptides qualified as inhibitors of apoptosis. First proteins of IAP family were discovered in baculovirus (insect viruses) and were shown to be able to inhibit cell death in the host due to a viral infection. IAPs were also found in cells of many species of eukaryote like in yeast, nematode as well as in birds and mammals including humans [8,13-15].

IAPs prevent cell death by binding and inhibiting caspases. Their function is to disturb apoptotic signaling by forming complexes with proteolytic enzymes (caspases), adaptor proteins, transcription factors and proteins which block their activity. Inhibitors of apoptosis are capable of inhibiting programmed death in two different ways: receptorial and mitochondrial (they inhibit the activity of caspases $3,7,9$ - they are inhibitors of the common way activation) $[11,10,16]$. Some of them are also involved in cell cycle regulation and intracellular signal transmission. They may act as ubiquitin ligases and contribute to the degradation of caspases [11,14,16-18] .

IAPs proteins are composed of polypeptide chains of about 150-1500 amino acids characterized by the existence of two sequence motifs $[13,18,19]$ :

- In N-terminus there is BIR domain (Baculoviral IAPRepeat)

- In C-terminus there is zinc finger RING (not in all IAPs).

BIR domains are composed of about 70 amino acid residues and bind zinc ion. Each domain is a globular structure, functionally independent. BIR domains of two IAP proteins: Bruce and survivin, are larger than in others and contain around 100 amino acids. These domains are bound by connectors. RZF domain is of zinc finger structure and shows E3 ligase activity of ubiquitin-protein. RZF plays an important role in autoubiquitination of IAPs protein and target proteins. The process of ubiquitination modifies proteins by their covalent coupling with a single molecule of ubiquitin - monoubiquitination, or with numerous ubiquitin molecules connected with isopeptide bonds - polyubiquitination. Proteins which were connected by a couple of ubiquitin molecules are generally degraded in the $26 \mathrm{~S}$ proteasome. Monoubiquitation mediates the nonproteolytic activity such as gene silencing, DNA repair, and signal transduction. Ubiquitination is an ATP-dependent process which involves the following three enzymes (E1, E2, E3), characterized by the presence of the UBC domain with cysteine residues [8,9,13,19,20].

In a man, eight IAP proteins were detected. They were classified into three groups based on homology of BIR domains and the presence or absence of RZF:

- 5 IAP proteins are classified into the first group: XIAP (also called BIRC4), c-IAP1 (BIRC2), c-IAP2 (BIRC3), ILP2 (BIRC8), livina (BIRC7). A characteristic feature of this group is the presence of RZF domain in all proteins. Some of the proteins are characterized by the presence of three BIR domains (XIAP, cIAP1, cIAP2). Other proteins (ILP2, livina) are characterized by the presence of one BIR domain.

- The second group includes one NAIP protein (BIRC1). This protein has three BIR domains, but lacks RZF.

- The third group includes two proteins: survivin (BIRC5) and Bruce (BIRC6, Apollon). These proteins have only one BIR domain and they lack RZF $[8,13,19,21,22]$.

The role of the IAP family of proteins and their antagonists in the regulation of cell death suggests that they may participate in the development of cancer. Overexpression of IAP proteins and/or reduced expression of their antagonists resulting from a genetic defect may lead to the formation of "antiapoptotic profile" of a cell, thus facilitating the proliferation of a cancerous clone. Proteins that antagonize the IAP include the Smac/DIABLO, HtrA2/Omi. They are proapoptotic factors and prevent the inhibition of caspases through the IAP proteins [14,17,19,21].

The BIRC6 gene, which is located in the short arm of chromosome 2, encodes the BRUCE protein that is a member of Class III Inhibitors of Apoptosis (IAP). The Bruce protein is not fully understood. It demonstrates multidirectional action. The BIRC6 gene is involved in the process of apoptosis inhibition, influences cell viability and cell division, exhibits an increased gene expression in many neoplasms, and it probably contributes to cell immunity against apoptosis induced by the treatment. This is why many researchers see the BIRC6 gene as a potential target for new treatment strategies [13].

The BIRC5 gene encodes the survivin protein. The function of this protein is the inhibition of the activation of initiator and effector caspases, which, in consequence, leads to the inhibition of programmed cell death. An increased expression occurs in the $\mathrm{G} 2 / \mathrm{M}$ phase of the cell cycle. An 
increased expression of surviving is observed in damage to the vessel wall in vessels with atherosclerotic lesions and in which apoptosis takes place. This process does not take place in healthy vessels $[21,22,24,25]$.

\section{AIM}

The aim of the study was to assess the gene expression of Class III IAPs: BIRC5 and BIRC6 in normal peripheral blood lymphocytes and in peripheral blood lymphocytes of patients diagnosed with atherosclerosis. The study also tries to analyse the relation between gene expression and the selected clinical characteristics of the disease.

\section{MATERIAL AND METHODS}

The study was carried out on mononuclear cells of peripheral blood taken from the 21 in-patients of the Chair and Department of Vascular Surgery and Angiology in Lublin. The patients were diagnosed with arterio-atherosclerosis. The tested group of patients consisted of 7 women and 14 men, aged 57-87. The process of taking and analyzing the material was performed in accordance with the study protocol approved by the Bioethical Commission and Head of the Clinic. The control group consisted of mononuclear cells of peripheral blood taken from 10 healthy volunteers.

The mononuclear cells were isolated from whole blood using the band centrifugation technique with the use of the Lymphoprep reagent. The analysis was carried out in the RNA samples obtained from lymphocytes. The isolation of the complete cellular RNA from cells was carried out using the modified Chomczyński and Sacchi method with the use of the Sigma TRI-Reagent. The specific fragment of the analysed gene was obtained through amplification with the use of cDNA synthesized in the reaction of reverse transcription. The analysis of expression was conducted using the RealTime PCR method with the use of the Applied Biosystems StepOne System. In the analysed cases, the level of expression of the tested genes was compared to the level of expression of the B2M reference gene that was amplified in the same amount of RNA isolated from the same cells.

\section{RESULTS}

The analysis was conducted using the RQ Study software; the results are presented in FIGURE 1. The average relative BIRC6 gene expression in the group of patients suffering from atherosclerosis was 11.42. While the average relative BIRC5 gene expression was 3.25. The highest average BIRC6 expression was recorded in the CHN05 test and it amounted to 189.98. In the case of the BIRC5 gene, the highest relative expression was observed in the CHN20 test, i.e. 19.01. The lowest relative expression for both, the BIRC6 and BIRC5 genes was recorded in the CHN19 test, and it amounted to 0.22 and 0.18 , respectively.

The study showed that the mRNA of the BIRC5 and BIRC6 genes is present in the cells of the patients suffering from atherosclerosis, as well as in the cells of the healthy individuals. The cells taken from the patients with arterialatherosclerosis were mainly characterized by increased gene expression in comparison to normal cells. In 3 tests, decreased BIRC6 gene expression relative to the control was observed in 4 tests. In the CHN05, CHN09, CHN11, and CHN13 tests, the result showing the BIRC6 gene expression was not reported.

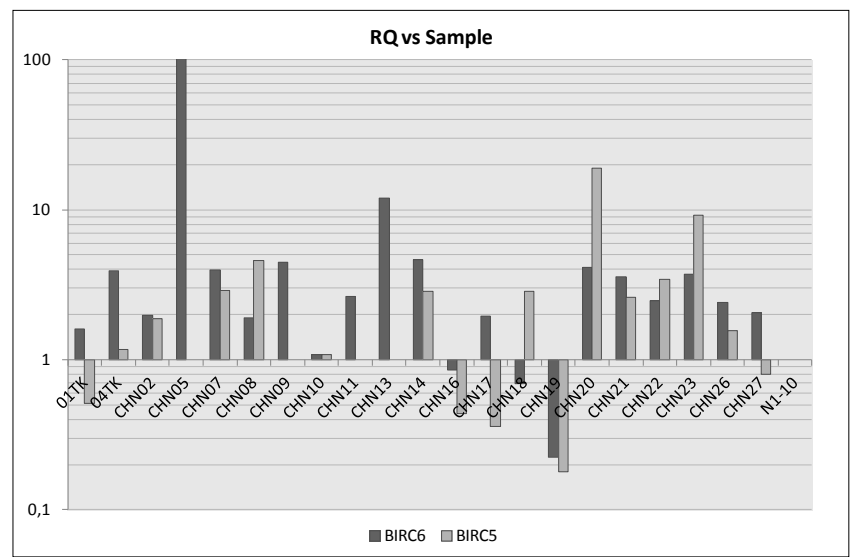

FIGURE 1. Relative $B I R C 5$ and $B I R C 6$ gene expression in peripheral blood lymphocytes in the patients with atherosclerosis. Calibrator normal N1-10 cells.

Increased BIRC6 and BIRC5 gene expression in the cells of the patients with atherosclerosis can suggest an increased amount of the inhibitor protein BRUCE and survivin, and also decreased sensitivity of cells to apoptosis. In the case of the patients who had significantly higher expression of the BIRC6 gene in lymphocytes compared to the norm, hypertension and diabetes mellitus were more common. Relative higher expression of the BIRC6 and BIRC5 genes was reported in the patients who smoke cigarettes. The correlation between the expression of the BIRC6 and BIRC5 genes in the cells, with the level of lipids of the patients with atherosclerosis was not detected.

\section{CONCLUSIONS}

In the early stages of the development of atherosclerosis, programmed cell death can weaken atherosclerotic lesions that favour the stabilisation of atheromatous plaque, reducing the accumulation of cells, and inhibiting the excessive growth of the internal layer. In advanced changes, the apoptosis of the cells in the plaque may be one of the pathogenic factors of atherosclerosis. This is because it contributes to the cracking of the plaque and forming of the clot. It leads to severe clinical complications. Clinical and experimental data demonstrated that $\mathrm{T}$ and $\mathrm{B}$ lymphocytes present in the plaque are implicated in the atherogenic process producing pro- and anti- inflammatory cytokines influencing fibrous cap integrity and plaque stability [25]. This is why the inhibition of apoptosis through survivin and the BRUCE protein can have positive influence on the course of the disease in the advanced stage $[2,3,22]$. 


\section{REFERENCES}

1. Urbanek T, Skop B, Wilczok T, et al. Apoptoza w schorzeniach układu naczyniowego - implikacje kliniczne, przegląd piśmiennictwa. Chir Pol. 2003;5:47-58.

2. Zapolska-Downar D, Sygitowicz G, Jarosz M. Znaczenie apoptozy w patogenezie miażdżycy. Kard Pol. 2008;66:347-57.

3. Stoneman V, Bennett M. Role of apoptosis in atherosclerosis and its therapeutic implications. Clin Sci. 2004;107:343-54.

4. Zagrodzki P. Łaszczyk P. Selen a choroby układu sercowo-naczyniowego - wybrane zagadnienia. Post Hig Med Dosw. 2006;60:624-31.

5. Mitrus I, Missot-Kolka E, Szala S. Geny proapoptotyczne w terapii genowej nowotworów. Współ Onkol. 2001;5:242-9.

6. Ghavami S, Hashemi M, Ande SR, et al. Apoptosis and cancer: mutations within caspase. J Med Genet. 2009;46:497-510.

7. Smolewski P, Grzybowska O. Regulacja procesu apoptozy komórek w celach terapeutycznych - dotychczasowe doświadczenia i perspektywy rozwoju. Acta Haematol Pol. 2002;33:393-401.

8. Wei Y, Fan T, Yu M. Inhibitor of apoptosis proteins and apoptosis. Acta Biochim Biophys Sin. 2008,4:278-88.

9. Malinowska I. Rola apoptozy w patogenezie i leczeniu nowotwór układu hematopoetycznego. Post Hig Med Dosw. 2004;58:548-59.

10. Korzeniowska-Dyl I. Kaspazy - struktura i funkcja. Pol Merk Lek. 2007;138:403-7.

11. Grzybowska-Izydorczyk O, Smolewski P. Rola białek z rodziny inhibitora apoptozy (IAP) w chorobach rozrostowych układu krwiotwórczego. Post Hig Med Dosw. 2008;62:55-63.

12. Stańczyk M, Majsterek I. Apoptoza-cel ukierunkowanej terapii przeciwnowotworowej. Post Biol Kom. 2008;35:467-84.

13. Rupniewska Z, Koczkodaj D, Wąsik-Szczepanek E. BRUCE/Apollon i jego rola w rodzinie białek hamujących apoptozę. Acta Haematol Pol. 2006;37:329-37.

14. Wright CW, Duckett CS. Reawakening the cellular death program in neoplasia through the therapeutic blockade of IAP. J Clin Invest. 2005; 115:2673-8.

15. Deveraux QL, Reed JC. IAP family proteins suppressor of apoptosis. Genes Dev. 1999;13:239-52.

16. Bielak-Żmijewska A. Mechanizmy oporności komórek nowotworowych na apoptozę. Kosmos. Problemy Nauk Biologicznych. 2003;52:157-71.

17. Rumble JM, Duckett CS. Diverse function within the IAP family. J Cell Sci. 2008;121:3505-7.

18. Verhagen AM, Coulson EJ, Vaux DL. Inhibitor of apoptosis proteins and their relatives: IAPs and other BIRPs. Genome Biol. 2001;2(7):3009.

19. Grzybowska-Izydorczyk O, Smolewski P. Białka inhibitorowe apoptozy z rodziny inhibitorów apoptozy (IAP) i ich antagoniści: rola biologiczna oraz potencjalne znaczenie w karcinogenezie i celowanej terapii przeciwnowotworowej. Acta Haematol Pol. 2009;40:593-612.

20. Yang LY, Li XM. The IAP family: endogenous caspase inhibitors with multiple biological activities. Cell Res. 2000;10:169-77.

21. Kaczmarek-Borowska B, Zmorzyński Sz, Filip A. Biologiczna rola surwiwiny. Współ Onkol. 2008;10:437-40.

22. Rupniewska Z, Koczkodaj D, Wąsik-Szczepanek E. Ekspresja surwiwiny i jej znaczenie kliniczne (Część II). Acta Haematol Pol. 2005;36:381-7.

23. Yamamoto K, Abe S, Nakagawa Y, et al. Expression of IAP proteins in myelodysplastic syndromes trans forming to overt leukemia. Leuk Res. 2004;28:1203-11.

24. Sokołowska J, Urbańska K. Biologiczna rola surwiwiny i jej znaczenie kliniczne. Życie Wet. 2011;86:963-6.

25. Hansson GK, Libby P. The immune response in atherosclerosis: a double-edged sword. Nat Rev Immunol. 2006;6:508-19.
Acknowledgements. This study was supported in part by founds from: Project "The equipment of innovative laboratories doing research on new medicines used in the therapy of civilization and neoplastic diseases" within the Operational Program Development of Eastern Poland 2007-2013, Priority Axis I Modern Economy, Operations I.3 Innovation Promotion and Projects: The "Study grants for PhD II" co-financed by the European Social Fund of the State Budget and Budget Lublin under Human Capital Operational Programme Priority VIII Regional human resources, Measure 8.2 Transfer of knowledge, Measure 8.2.2 Regional Innovation Strategies and The "Expertise and Competence" - the development of the Medical University of Lublin "co-financed by the European Social Fund within the Human Capital Operational Programme 2007-2013

\section{Corresponding author}

Janusz Kocki

Department of Clinical Genetics, Medical University of Lublin

11 Radziwiłłowska Str., 20-080 Lublin, Poland

E-mail: janusz.kocki@tlen.pl

tel: +48 81 528-84-08, fax: +48 81 528-84-08 